\title{
Transatlantica
}

Revue d'études américaines. American Studies Journal

\section{The American Landscape: from an Ideological to an Ecological Object in Oxbow Archive by Joel Sternfeld}

\section{Helena Lamouliatte}

\section{(2) OpenEdition}

1 Journals

\section{Electronic version}

URL: https://journals.openedition.org/transatlantica/17168

DOI: 10.4000/transatlantica. 17168

ISSN: 1765-2766

\section{Publisher}

Association française d'Etudes Américaines (AFEA)

\section{Electronic reference}

Helena Lamouliatte, "The American Landscape: from an Ideological to an Ecological Object in Oxbow Archive by Joel Sternfeld", Transatlantica [Online], 1 | 2021, Online since 12 July 2021, connection on 01 February 2023. URL: http://journals.openedition.org/transatlantica/17168 ; DOI: https://doi.org/ 10.4000/transatlantica.17168

This text was automatically generated on 1 February 2023.

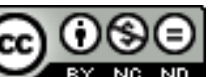

Creative Commons - Attribution-NonCommercial-NoDerivatives 4.0 International - CC BY-NC-ND 4.0 https://creativecommons.org/licenses/by-nc-nd/4.0/ 


\title{
The American Landscape: from an Ideological to an Ecological Object in Oxbow Archive by Joel Sternfeld
}

\author{
Helena Lamouliatte
}

\section{Introduction}

1 In his book, Americans and Their Forests, geographer Michael Williams demonstrates that the American landscape had already undergone significant transformations by the time the European settlers arrived. Native American New England tribes, he explains, used specific agricultural techniques, such as slash and burn farming, a form of shifting agriculture where the natural vegetation is cut down and burned, as a method of clearing the land for cultivation. He also describes how industrialization and the intensive agricultural development which occurred between 1810 and 1860 further transformed the original landscape: "Much of the 'natural' forest remained, but the forest was not the vast, silent, unbroken, impenetrable and dense tangle of trees beloved by many writers in their romantic accounts of the forest wilderness" (Williams 33).

2 As a result, the bend of the Connecticut River, called "The Oxbow," the subject chosen by Thomas Cole (1801-1848) for his painting View from Mount Holyoke, Northampton, Massachusetts, after a Thunderstorm (1836) (Fig. 1) was far from being a "natural" site at that time. 
Fig. 1. Thomas COLE. View from Mount Holyoke, Northampton, Massachusetts, after a Thunderstorm The Oxbow, 1836. The Metropolitan Museum of Art.

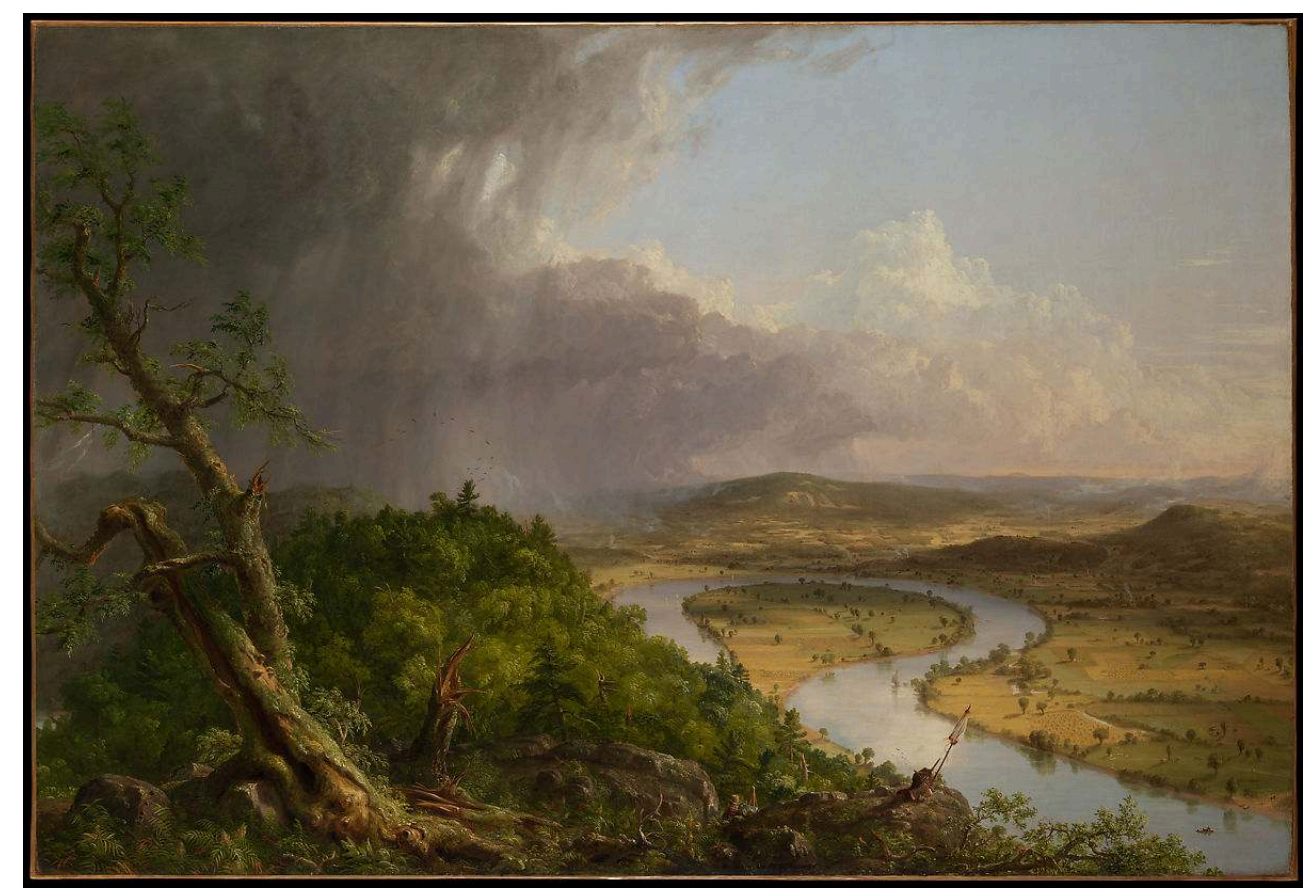

A closer look shows that a vast portion of land in the background, next to the bend, had already been cleared for agricultural purposes. Williams explains that a sustained demand for wood kept increasing throughout the first half of the nineteenth century:

At the same time [from 1830 onward] agricultural clearing continued unabated alongside the upsurge of industrialization. The steady stream of immigrants created unprecedented demands on the forests for farmland as the population swelled from 7.2 million in 1810 to nearly 12.8 million in 1830 then to 31 million by 1860. [...] Wood and wooden products permeated American life. (Williams 146-147)

The geographer's findings materialize landscape theories, such as Mark Dorrian's and Gillian Rose's and their definition of the concept of landscape that they develop in their introduction to Deterritorialisations: Revisioning Landscapes and Politics (2003). On the one hand, from a geographical, sociological or anthropological perspective, landscape refers to a set of daily practices and experiences; on the other hand, and from an aesthetic perspective this time, landscape refers to a set of representational practices (Dorrian and Rose 12). Dorian and Rose's publication was instrumental in recognizing landscape as the core topic of a wide variety of disciplines by expanding the focus of the political aspects of landscape, its ideological character and effects, far from the romantic notion of "natural" settings. They highlight four "productive" tensions pertaining to the concept of landscape. First, through the tension between the material and the subjective, "landscape can be seen in terms of a screen between a material potentiality and a subject making meaning, feeling and fantasy from it" (16). Then, they point to the tension between the "inside" and the "outside," with the eye of the viewer as the pivot point of perspective, that separates "what is contained within the limits of a landscape" and "the observer of that landscape" (16). Thirdly landscapes often combine multiple timelines: past, present and future. Indeed, landscapes may become "productive in relation to a past or to a future, but that relation is always drawn with regard to a present" (17). To finish, "landscape can also mediate between the 
representable and the non-representable" (17), a variation on the idea of landscape as a screen between matter and subjectivity.

In Land Matters (2011), Liz Wells illustrates Dorrian and Rose's views by demonstrating how the visual interpretation of land as landscape mirrors and strengthens contemporary political, social and environmental concerns. In her introduction, Wells explains that all the works that she has selected take into account the human presence: "Vistas encompassing both nature and the changes that humans have effected on the natural world" (2). She uses a photograph by Joel Sternfeld, Mount Rushmore National Monument, Black Hills National Forest, South Dakota, August 1994 (1994) that can be interpreted as both a political and ecological statement which aptly exemplifies Sternfeld's subtle visual strategy. Wells explains how in 1877 the American Congress broke the 1868 treaty deeding the Black Hills of South Dakota to the Great Sioux Nation when gold was discovered in the area. Mount Rushmore monument was commissioned later, in the 1920s, by the state of South Dakota to attract tourists to the area. Sternfeld's photograph shows the monument jutting out of the background through an artificial gap created in a line of pine trees that were shorn through to allow a massive range of projectors to illuminate the sculpture. The monument, framed by tall trees, looks like an ugly scar protruding from the landscape. The discrepancy between the natural and human elements is further enhanced by the rows of rusty metal projectors in the foreground.

4 Thus, at the time Thomas Cole painted "the Oxbow," his representation of the viewpoint from the top of Mount Holyoke followed very specific aesthetic and cultural criteria, ${ }^{2}$ but it also conveyed an undeniable political dimension also expounded in Joel Sternfeld's project, Oxbow Archive, albeit from an extremely different perspective.

\section{Joel Sternfeld: Modern Perspectives on an Iconic American Painting}

5 The iconicity of Cole's painting is one explanation for Sternfeld's choice of location for Oxbow Archive. The View from Mount Holyoke, Northampton, Massachusetts, after a Thunderstorm, known as The Oxbow, was first exhibited at the National Academy Spring Exhibition in 1836 and has been exhibited at the Metropolitan Museum of Art since 1908. This impressive painting ${ }^{3}$ shows a sweeping panorama of the surrounding valley, from the peak of the Holyoke range. It is certainly one of the most famous landscape paintings in American history. Ellwood C. Parry III states that: "Thomas Cole's rendering of the oxbow meander on the Connecticut River as seen from the summit of Mount Holyoke in western Massachusetts has achieved hyper-iconic status in the history of American landscape painting" (7). It was created by an artist who is called the founding father of American landscape and whose reputation had been firmly established as early as $1844 .^{4}$

6 Cole's pedagogical role in educating the American audience was also paramount. He managed to elaborate a visual topos, combining traditional elements from European painting and local natural features that allowed him to establish a specific typology of national visual motifs, based on preexisting aesthetic categories. In a letter written in 1827 to Robert Gilmor, a Baltimore merchant and one of his most influential patrons, Cole emphasizes the subjectivity of the creative process and the necessary 
interpretation of reality that painting requires: "Raphael's pictures, those of all the great painters are something more than mere imitations of nature as they found it. If the imagination is shackled, and nothing is described but what we see, seldom will anything truly great be produced either in Painting or Poetry." The functions of The Oxbow are thus both conceptual and metaphorical. First of all, it is supposed to "landscape" nature, according to W.J.T. Mitchell's concept that defines landscape "not as an object to be seen or a text to be read, but as a process by which social and subjective identities are formed" (1). And secondly, this painting promotes and displays the domestication of the American territory, which was a prevailing ideological factor at the time. Indeed, on the website of the Metropolitan Museum of Art, the painting is described as follows:

Here the artist juxtaposes untamed wilderness and pastoral settlement to emphasize the possibilities of the national landscape, pointing to the future prospect of the American nation. Cole's unequivocal construction and composition of the scene, charged with moral significance, is reinforced by his depiction of himself in the middle distance, perched on a promontory painting the Oxbow. He is an American producing American art, in communion with American scenery. (metmuseum.org)

7 Dorrian and Rose's "multiple timelines" are useful here; revisiting the past with a $20^{\text {th }}$ century mindset, Sternfeld thus participates in debates about American wilderness as defined by Roderick Nash. ${ }^{6}$

Moreover, Cole created a new representational technique for this painting that Alan Wallach defines as "panoptic sublime."" Wallach combines here Foucault's reference to power and the aesthetic category of the sublime, its "totalizing vision which might be called panoramic" (83). For him this technique became the paradigm of the American land as landscape, by visually demonstrating man's appropriation of nature. In the midnineteenth century, the tropes of the American landscape were established and re-used by many artists, who either celebrated the wilderness of primitive forests, like Albert Bierstadt in Landscape (1867-1869), or pastoral scenes such as Conway Valley New Hampshire (Date unknown). ${ }^{8}$ Like Thomas Cole, they sometimes combined the two categories, as can be seen for example in Frederic Edwin Church's Highlands of the Hudson River (1866). However, according to Greg Garrard, the concept of the pastoral was more relevant to the European tradition, while the one of wilderness was more adapted to the representation of the New Worlds (United States, Canada, and Australia), "with their apparently untamed landscapes and the sharp distinction between the forces of culture and nature" (59-60). In the field of American painting, Garrard states that in the $18^{\text {th }}$ century, the concept of the sublime was a popular cultural appropriation of the concept of wilderness in literature, but also in painting (63). For Sternfeld, Oxbow Archive proposes the re/interpretation of what can be seen as the epitome of American landscape art. Just as Cole's artwork embodied Dorrian and Rose's tension between the material and the subjective, Sternfeld's images represent landscape as a "screen" between the sheer materiality of nature and the artist's feelings and creativity (Dorrian and Rose). 


\section{Joel Sternfeld: Representing the American Landscape in the $21^{\text {st }}$ Century}

Before studying the series of photographs entitled Oxbow Archive, ${ }^{9}$ it seems necessary to highlight some key elements about the topographic evolution of the Oxbow site after Thomas Cole had painted it. Because of intensive plowing near the river bend in 1839 (the cultivated fields are clearly visible in the lower part of the painting), ice blocked the natural flow of water during the following winter, which flooded the nearby area, and created a new river arm. The landscape painted by Cole in 1836 had thus already undergone a significant transformation three years later.

As early as 1821, a plain house offering refreshments to the walkers was built at the top of the mountain, which Cole deliberately chose to edit out. ${ }^{10}$ Shortly after, local entrepreneurs built a road that enabled tourists to reduce the climb upward by half. In 1851, the house was turned into a hotel, called Summit House (or Prospect House). Between 1851 and 1900, a horse-drawn, later electric, tramway was added in order to help visitors arriving at the steamboat pontoon built on the Connecticut River to ascend the steep slope. The tramway gradually fell into disrepair and was taken down in the 1960s. Summit House faced a similar fate and was set to be demolished in the 1970 s, but was finally refurbished in the 1980s after being granted heritage status.

11 Nearly two hundred years after Thomas Cole painted The Oxbow, the American photographer Joel Sternfeld (born in New York in 1944) took a series of photographs of a place called the East Meadows, situated in the bottom right-hand part of Cole's painting, and located on the East side of the river bend.

Fig. 2. Map of the Oxbow of the Connecticut River, Oxbow Archive, 2008.

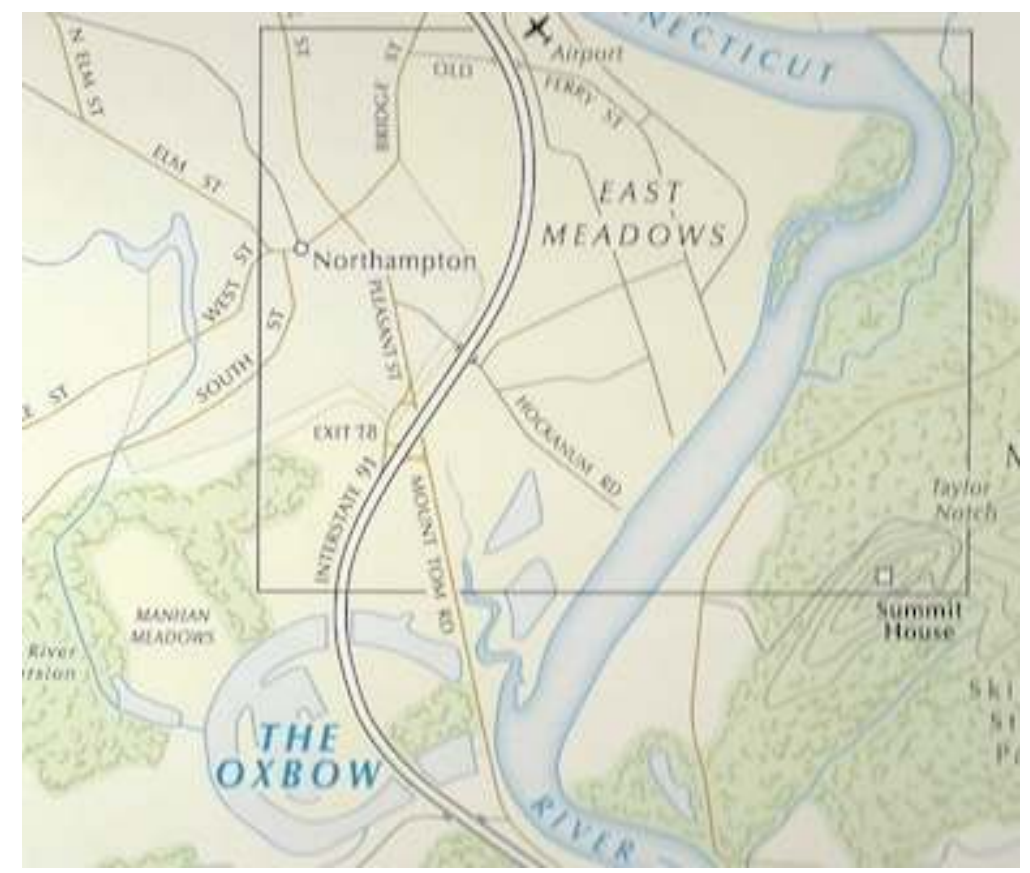

These photographs were reproduced in a book entitled Oxbow Archive, published in 2008. Sternfeld had already photographed this part of the site in 1978, while scouting the country for another series, American Prospects (1987). Late October 1978, a photograph 
showing a sparse planted forest is inserted between the two title pages of Oxbow Archive. When Sternfeld went back there in 2006, the northern end of the Oxbow had been cut off to build Interstate 91 (Fig. 2). The destructive side-effects of progress that Cole had foreseen were now clearly visible, as well as the contemporary impact of global warming. The book comprises 77 photographs that were taken over the course of a year and a half, between July 2005 and March 2007. Sternfeld's choice of subject matter, a plain potato and corn field surrounded by forests-typical crops in this part of the United States-highlights the conceptual distance between his project and Cole's. The site is neither sublime, nor picturesque, and Sternfeld's artwork doesn't contribute to the glorification of the American landscape. The photographs follow the seasonal cycles, with no other seemingly common thread.

13 Right from the start Sternfeld establishes an intericonic relation with Cole's painting, which could be named metapicturality (to take up Liliane Louvel's refashioning of Gérard Genette's terminology for the visual arts), ${ }^{11}$ or even "patent metapicturality," judging from the book title and the chosen layout. Indeed, Cole's painting is inserted between two maps of the area and the last photograph, July, 13, 2006 (Fig. 3) at the end of Oxbow Archive. No descriptive or explanatory texts accompany the photographs, and the terse titles only provide the date on which the shots were taken. There is a single textual element, an epigraph taken from Ralph Waldo Emerson's 1836 Nature-“To the attentive eye, each moment of the year has its own beauty, and in the same field, it beholds, every hour, a picture which was never seen before, and which shall never be seen again" (10)-a quotation that echoes Cole's contemplation of the transient nature of the "American Scenery," as depicted in his essay.

Fig. 3. Joel STERNFELD. July 13, 2006. The East Meadows, Northampton, Massachusetts. () Joel Sternfeld

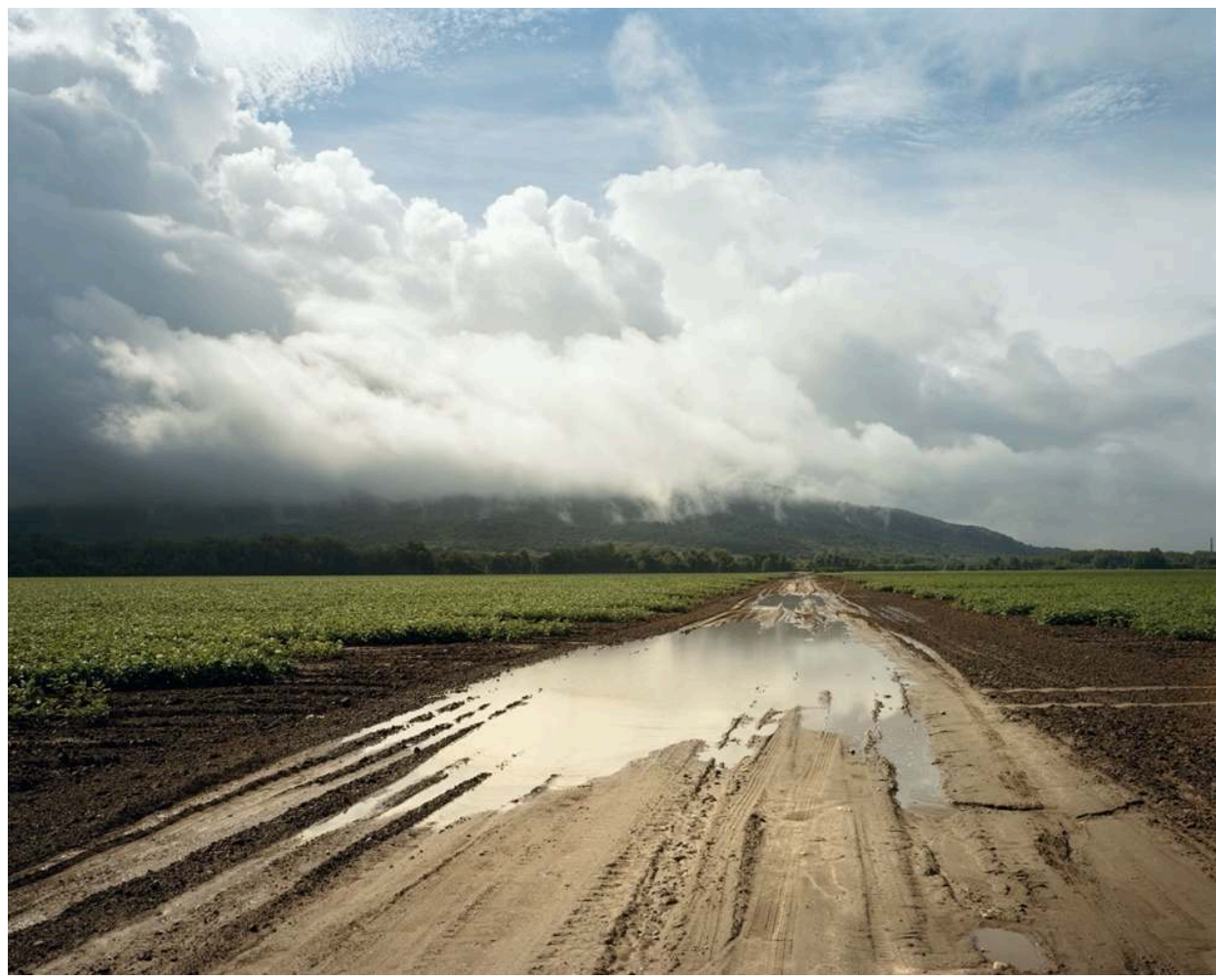



departs from Cole's panoramic vista and takes the photographs at the bottom of the valley, since the purpose of his work is no longer to dominate nature visually. Secondly, he has decided to immerse himself in the heart of nature to give a new insight of the nature that we perceive and of the very nature of our perception. We no longer feel the power of the viewer's gaze, as depicted in Cole's painting and described by Wells: "Spectatorship becomes, in effect, a symbolic exercise of control-of mind over matter -articulated via the pleasure of contemplation" (5). The sensation is closer to an instinctive and sudden reaction reminding the viewer of Roland Barthes's punctum, ${ }^{12} \mathrm{a}$ concept whereby he describes specific aspects of the photographic image. The punctum helps Barthes refer to his reaction before unexpected details in images-a seminal element in Sternfeld's work, who doesn't resort to staged scenes, contrary to other famous contemporary American photographers, like Jeff Wall ${ }^{13}$ or Gregory Crewdson. We should add that the size of the exhibition photographs was extremely large, which allowed the viewers to feel visually immersed in the surrounding scenery, and triggered a strong emotional response to the images. Size varies from medium to long shot, with a few panoramic still shots. The meticulous focus on perspective and depth of field, which can be noticed in many images, is made possible thanks to the old fashioned "view camera" that was used by the pioneers of American photography, and became popular thanks to Ansel Adams's famous landscapes, ${ }^{14}$ like The Tetons and the Snakes (1942). ${ }^{15}$

Nevertheless, Sternfeld doesn't explore the concepts of the sublime and the picturesque in an obvious manner like Adams. Instead, he uses the technical specificities of the view camera in a subdued and distorted way. He creates framewithin-frame and crisscrossing patterns that play with perspective and vanishing points and question our notion of perception. The landscape photographs are often shown from a very plain and banal frontal perspective, while the series of landscapes simply mark seasonal cycles, as can be seen in March 27, 2007, April 29, 2007, July 8, 2006, or September 12, 2006 (online portfolio of the 2008 exhibition at Luhring Augustine gallery). Sternfeld's work in Oxbow Archive invites the viewer to become immersed in landscape, which is transformed into a place of meditation, evoking the intuitive process of poiesis-poetry as making. The internalization process is triggered by the abundance of images, multiple viewpoints (although they always remain at ground level and there are no high or low-angle shots), and by the highly symbolic theme of seasons, associating mortality and regeneration. ${ }^{16}$ This process evokes François Cheng's concept of "microcosm-macrocosm", developed in his book Vide et Plein: "The painter aims at creating a psychical space where man meets the vital current; more than an object to look at, a painting is something to experience" (Cheng 101, my translation). Even though these images have a strong power of evocation, we shouldn't forget that if the indexical nature of photography is one of its many fascinating aspects, a photograph remains an image designed and filtered by subjectivity.

\section{Joel Sternfeld's Environmental Commitment}

This series of "time landscapes" offers a visual and conceptual reading of American landscape in the $21^{\text {st }}$ century. So as to grasp their scope fully, these photographs should be seen alongside two other political series made by Sternfeld, Sweet Earth: Experimental 
Utopias in America published in 2007, depicting communities who explore alternative lifestyles, and more particularly, When it Changed, which is composed of portraits of international delegates at the 2005 Montreal UN climate change summit. Sternfeld, who seldom comments on his work, wrote a newspaper article in the Guardian in 2013, in which he remembers how he felt when he took the photographs: "What I heard and saw at this conference shocked me like nothing I've ever experienced. [...] In the opinion of nearly all the participants, not only was climate change occurring, it was also about to reach a tipping point and become irreversible" (Sternfeld, 2013). Sternfeld's art has an undeniable political dimension, which was manifest since his first series of photographs, American Prospects, was exhibited (the book was published in 1987, and reprinted in 2004). Liz Jobey quotes the photographer: "His quest, he says, was that 'of someone who grew up with a vision of classical regional America and the order it seemed to contain, to find beauty and harmony in an increasingly uniform, technological and disturbing America." In When it Changed, the portraits are presented alongside newspaper extracts and quotes from scientific academic journals supposed to establish the timeline of this global catastrophe. When analyzing Oxbow Archive we should keep in mind the message conveyed by When it Changed, even though the deadly impact of humans on their natural environment is depicted through a very subtle dystopian mode.

17 As environmental concerns were starting to pervade American art, ecocriticism developed as a field of research. Some scholars started to "broaden art-historical inquiry and illuminate even the most seemingly familiar works" (Braddock 26) by using ecocritical analytical frameworks. Alan C. Braddock's definition is particularly interesting for art history:

Ecocriticism emphasizes issues of environmental inter-connectedness, sustainability, and justice in cultural interpretation. When historically oriented, ecocriticism may bring attention to neglected evidence of past ecological and proto-ecological sensibility or it may cast canonical works and figures in a new light by revealing previously unnoticed complexity regarding environmental concerns. (Braddock 26)

If ecocriticism enables art historians to decode the subtle environmental hints that some artists convey in their artwork, Aaron M. Ellison underlines that "romanticallyinfused notions of landscape" have systematically led painters and photographers to cut off men from their images, because of their nefarious impact on nature: "contemporary portrayers of landscapes [...] either recapture Thomas Cole's epigraphic vision of a perfect, unattainable world or a once-balanced world now despoiled by humanity" (10). To take this point further, Greg Garrard explains that the concept of wilderness means "a state of nature uncontaminated by civilization" (59), that is to say by either agriculture or industrialization..$^{17}$ Even if the force of the concept of wilderness was gradually tempered, he explains that: "as the wild places were disciplined by reason, an emergent Romantic sensibility was urging a revaluation, and in the eighteenth century wilderness was given a new inflection with the popularization of the idea of the sublime" (63).

Sternfeld follows his own subtle path and navigates the uncharted waters between a subdued version of Ansel Adam's overt sublime and the unassuming or even banal images that François Brunet calls the "beautiful but ugly photographs" (11). Sternfeld's implicitly dystopian images evoke the "aesthetics of detachment" described by Brunet. This expression used in French ("l'esthétique du détachement") sums up the visual 
strategy of a group of photographers (Rephotographic Survey Project) in the 1970s: "Par rapport au modèle d'Ansel Adams, le renversement n'était donc pas tant dans une prise de conscience politique des méfaits de l' 'altération' mais plutôt dans la recherche esthétique de cette 'altération' en tant que sujet, doublée d'une remise en cause de l'idéal transcendantaliste de l'artiste comme voyant doué de 'sentiment' : l'agir humain était réintroduit dans le sujet, mais toute 'âme' évacuée de la prise de vue” (12). Indeed, Sternfeld's aesthetic framework shares many features with a new generation of landscape photographers, who all started working in the 1980s, and more particularly with the most recent movement, the Third View, which focuses on the evolution of specific sites from an environmental perspective. ${ }^{18}$

In Sternfeld's art, criticism is hidden by the pervading aesthetic framework but highlighted by the serial mode. The negative impact of human intervention on nature is described in a similar way, through the repetition of fragmentary visual tropes, such as a campfire in April 28, 2006 or wheel marks in August 19, 2006 and March 25, 2007. The trees and shrubbery seem to be visually pushed back further and further in the distance in the photographs, until disappearing almost completely in July 29, 2005 and April 22, 2006 (Fig. 4).

Fig. 4. Joel STERNFELD. April 22, 2006. ๑ Joel Sternfeld

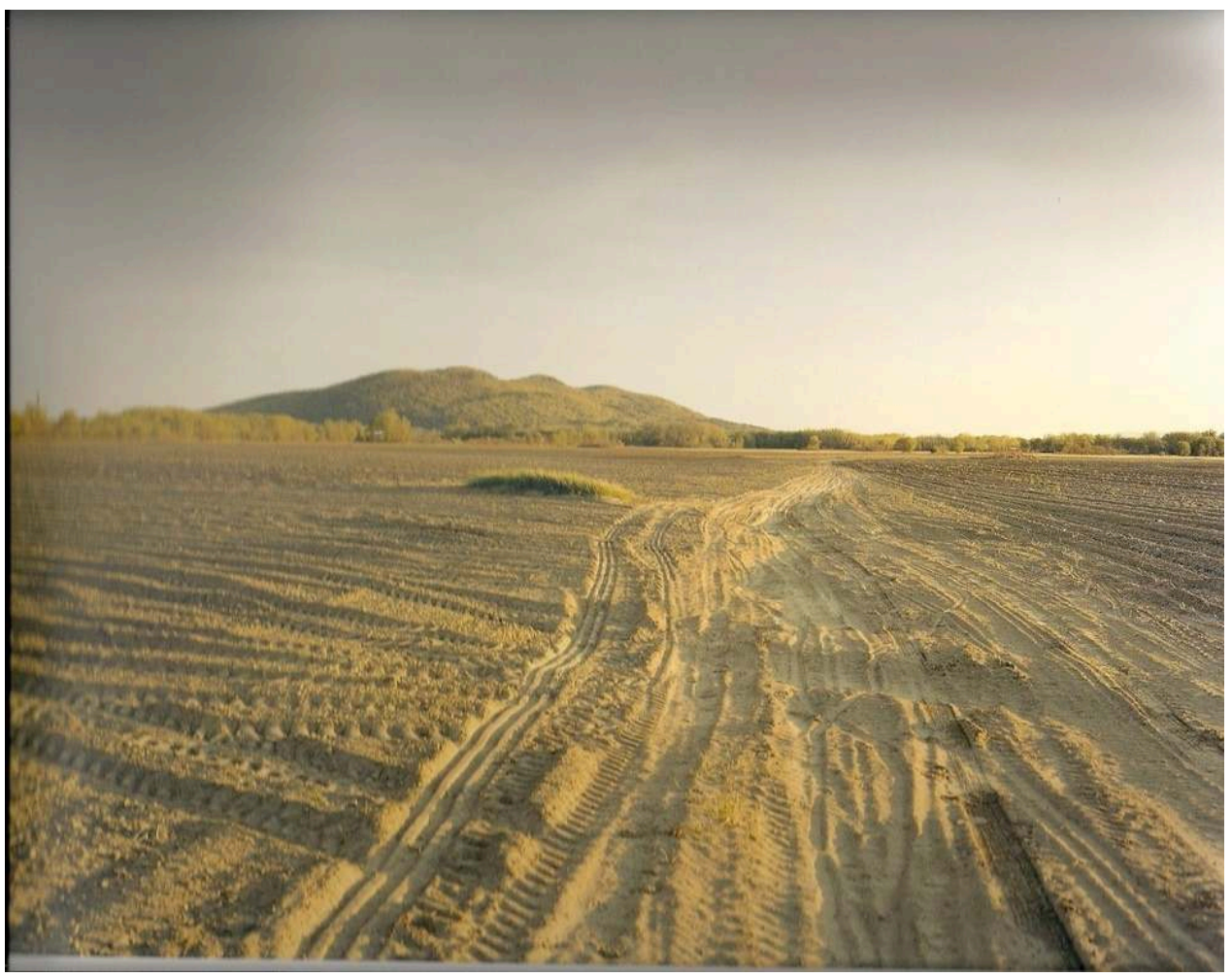

The series keeps treading the fine line of the utopia / dystopia dichotomy without ever losing its underlying tension. The atmosphere pervading numerous images often evokes the luminist tradition in American painting, depicting landscapes bathed in a seemingly supernatural light which makes every detail noticeable and brings out shimmering vibrant tones. Barbara Novak's description of luminism echoes the Transcendentalist philosophy quoted in the epigraph:

The clarity of this luminist atmosphere is applicable to both air and crystal, to hard and soft, to mirror and void. These reversible dematerializations serve to abolish 
two egos-first that of the artist, then the spectator's. Absorbed in contemplation of a world without movement, the spectator is brought into a wordless dialogue with nature, which quickly becomes the monologue of transcendental unity. (Novak 28-29)

Even though the label "luminism" has been the subject of heated debates in contemporary American art history, ${ }^{19} \mathrm{~J}$. Grey Sweeney cites a few recurring formalist features that are mentioned by the supporters of an American luminist mode (such as Novak)_-"limitless space and gleaming light," "luminosity," "motionless space" or "crisp light" (112-115). These elements are particularly relevant when describing Sternfeld's photographs in Oxbow Archive.

The epilogue of the series resorts to the same mode of silent, but quintessentially visual, denunciation. On the left page, we find Cole's painting, and on the right, Sternfeld has chosen a photograph entitled July 13, 2006 (Fig.3.) which exhibits all the standard features of the sublime-a spectacularly composed landscape image, in a sweeping panoramic format, with intense light, sharp shadows and large depth of field. As such it exemplifies W.J.T Mitchell's concept of "metapicture" (38):

[...] the use of metapictures as instruments in the understanding of pictures seems inevitably to call into question the self-understanding of the observer. This destabilizing of identity is to some extent a phenomenological issue, a transaction between pictures and observers activated by the internal structural effects of multistability" (Mitchell 57).

The photograph shows a fractured surface, cut in half by a muddy trench, like a bleeding wound. The viewer is faced with the underlying dialogic tension of the image, expressing both the power of "literal-topographic" representation (Wells 14), commonly found in landscape photography, and the expression of a critical and artistic subjectivity, the "evidently constructed" type of images (Wells 14). Mitchell's "effects of multistability" are present through the perfect framing of the road track in the foreground, gradually fading away as if it were swallowed by the forests and hills in the background, thereby illustrating the primeval clash between nature and culture. Also the crystal clear atmosphere seems to gift the viewer with a supernatural form of vision that enables her to perceive each plant blade or particle of mud. Third, the sunlight breaking through majestic billowing clouds is redolent of centuries of landscape painting and photography. These effects contribute to the "uncanniness," "ghostliness or spectrality" that Mitchell finds in metapictures, which are "a taking account of the persistence of the 'savage mind' at the dialectical heart of whatever we mean by the modern" (Grønstad and Vågnes).

Yet, the true ideological impact of July 13, 2006 can only be understood after a close reading of the information disseminated in the paratext, which exhibits two maps of the area: a large map of the Oxbow site entitled The Oxbow of the Connecticut River, and a closer shot, The East Meadows, corresponding to the area that was photographed by the artist. We thus understand that the last photograph, identified on the map by the title Endpiece, was taken along Hollow Road, a narrow road which was being widened at the time. Further north, Hollow Road intersects Interstate 91 highway, which cuts across the former river bend, the Oxbow. The place that was the epitome of the American sublime thanks to Thomas Cole's painting has been surrounded by agricultural land linked to the Connecticut river banks by a highway, and houses a recreational suburban space, the Oxbow marina. The ancient forests have been pushed into the background, and no longer stand for the original wilderness. While Thomas Cole lamented the destruction 
of the pristine American landscape as early as 1836 in his Essay on American Scenery, ${ }^{20}$ Sternfeld's images bear witness to the unrelentless commodification of landscape.

\section{However, Astrid}

[He] manages to create a thoroughly original take on photography as a politically committed art form. Moreover, his oeuvre offers occasion for an intriguing inquiry into photography's capacity to negotiate the tension between what is shown and what remains invisible, or hidden, in any given picture and, by extension, in the surrounding culture. (Böger 622)

This environmental dimension can thoroughly escape uninformed or inattentive viewers.

\section{Conclusion}

"Landscape photographs rarely 'shout'; rather, they are quietly assertive" (Wells 10). Liz Wells's remark is a good depiction of the photographs from Oxbow Archive that either follow a pattern of intrinsic oppositions within a single image, or of interrelated oppositions between several photographs of the series, without departing from the "quietly assertive" utopian / dystopian mode. Sternfeld's images can easily be misread, ${ }^{21}$ and it was undoubtedly the same issue with Thomas Cole's contemporaries, who certainly appreciated his glorification of the American landscape without perceiving his anguish towards its relentless domestication. Thus, beyond the topoi of the visual rhetoric of their times, both artists express a primeval attraction to nature and the notion of wilderness, and illustrate its importance in American culture from geographical, anthropological and political perspectives.

Both Cole and Sternfeld express the deep-rooted link they share with American landscape, which urges them to question this primeval relationship and to turn this emotional and intellectual process into images, thanks to the numerous opportunities offered by painting and photography. Their images, like multi-faceted prisms, reflect the complexity of our reactions when we encounter landscape, but also when we are confronted with its visual representation. This process is again aptly summed up by Liz Wells, when she says:

Our relationship to the environment in which we find ourselves, and of which we form a part, is multiply constituted: the real, perceptions of the real, the imaginary, the symbolic, memory and experience, form a complex tapestry at the heart of our response to our environment, and by extension, to landscape imagery. (Wells 2)

From a political and environmental perspective, Oxbow Archive may be regarded as a posthumous tribute to the wilderness that Cole was lucky to observe, even if it was already slightly different from its pristine state. Some of the most radical ecocritics, like Bill McKibben, share Sternfeld's anguish. McKibben wrote in 1989 in The End of Nature that we live in a "postnatural" world (60), which means that nature as a combination of processes and relations operating independently of any intentional human actions doesn't exist any longer. Miles Orvell, in an article about American photography after 9/11, coined the concept of "destructive sublime" which seems particularly relevant to describe Sternfeld's work in this series, reflecting at the same time on the aesthetic categories of landscape painting and man's visible interference: "some of these images have a quality of aesthetic excitement that threatens our ethical response to the images, producing a kind of double vision that cannot easily be 
untangled" (239). I would nevertheless stand with McKibben who states that despite the harmful impact of man on nature, it is still possible to imagine a place: "still wilderness, still pristine in our minds [...] so that we can still plausibly imagine wild nature" (56-57). If nature is undeniably doomed in real life, it still remains a lasting memory in our minds. This is precisely what Sternfeld manages to achieve through Oxbow Archive and it should remain one of the main purposes of art: the construction of an individual and collective imagination.

\section{BIBLIOGRAPHY}

BARTHES, Roland. Camera Lucida: Reflections on Photography. Translated from the French by Richard Howard. New York: Hill and Wang, 1981.

BÖGER, Astrid. "On-Site Disaster: Exposing Calamity in Twentieth-Century Art Photography." American Studies, vol. 58, no. 4. "Iconographies of the Calamitous in American Visual Culture," 2013, p. 607-624.

BRADDOCK, Alan C. "Ecocritical Art History." American Art, vol. 23, no. 2, 2009, p. 24-28.

BRUNET, François. "Photographie et écologie aux États-Unis : l'image à contre-emploi." Transatlantica, no. 1 |2017, journals.openedition.org/transatlantica/8878.

Accessed 29 April 2021.

BURNS, Sarah. Pastoral Inventions: Rural Life in Nineteenth-Century American Art and Culture. Philadelphia: Temple University Press, 1989.

CHENG, François. Vide et plein. Paris: Éditions du Seuil, 1991.

COLE, Thomas. "New York, December 25th 1827." Letters of Robert Gilmor to and from Thomas Cole 1826-1837 (36 letters) - B3-F8-complete.

nysl.nysed.gov/msscfa/sc10635.htm.

Accessed 4 May 2021.

COLE, Thomas. "Essay on American Scenery." American Monthly Magazine, no. 1, January 1836, p. 1-12.

DORRIAN, Mark, and Gillian ROSE, eds. Deterritorialisations: Revisioning Landscapes and Politics. London: Black Dog Publishing, 2003.

ELLISON, Aaron M. "The Suffocating Embrace of Landscape and the Picturesque Conditioning of Ecology.” Landscape Journal, vol. 32, no. 1, 2013, p. 79-94.

EMERSON, Ralph W. The Essential Writings of Ralph Waldo Emerson. Ed. Mary Oliver. New York: The Modern Library, 2000.

GENETTE, Gérard. Palimpsestes. Paris: Éditions du Seuil, 1982.

GRøNSTAD, Asbjørn, and Øyvind VÅGNES. “An Interview with W.J.T. Mitchell.” Image and Narrative. Issue 15, 2006, 
imageandnarrative.be/inarchive/iconoclasm/gronstad_vagnes.htm.

Accessed 11 May 2021.

HARGROVE, Eugene C. Foundations of Environmental Ethics. Upper Saddle River: Prentice Hall, 1989.

JOBEY, Liz. "Photographer Joel Sternfeld: close encounters.” The Guardian, 17 October 2008. guardian.co.uk/artanddesign/2008/oct/17/photography-joel-sternfeld.

Accessed 27 December 2017.

KELLY, Franklin. “A Passion for Landscape: the Paintings of Frederic Edwin Church.” Frederic Edwin Church. Ed. Franklin Kelly. Washington: National Gallery of Art, 1989.

KEMAL, Salim, and Ivan GASKELL, eds. Landscape, Natural Beauty and the Arts. Cambridge, UK: Cambridge University Press, 1993.

LEVITT, Linda. "Photography, Memory, and Tragedy: Joel Sternfeld's On This Site." Documentary Works, 2006.

www.documentaryworks.org/punctum/onthissite.htm.

Accessed 27 December 2017

LOUVEL, Liliane. L'Iconotexte revisité, ou les complicités de l'œil et de l'oreille. Rennes : Presses Universitaires de Rennes, 2002.

MADDOX, Kenneth W. "Thomas Cole and the Railroad: Gentle Maledictions." Archives of American Art Journal, vol. 26, no. 1, 1986, p. 2-10.

McCOUBREY, John W., ed. American Art, 1700-1960: Sources and Documents. Upper Saddle River: Prentice Hall, 1965.

McKIBBEN, Bill. The End of Nature. 1989. New York: Anchor Books, 1999.

Metropolitan Museum of Art. "View from Mount Holyoke, Northampton, Massachusetts, after a Thunderstorm-The Oxbow." Timeline of art history.

metmuseum.org/toah/works-of-art/08.228/.

Accessed December 2017.

MILLHOUSE, Barbara B. American Wilderness: The Story of the Hudson River School of Painting. Hensonville: Blackdome Press, 2007.

MITCHELL, W.J.T. Landscape and Power. 1994. Chicago: The University of Chicago Press, 2002.

MITCHELL, W.J.T. Picture Theory: Essays on Verbal and Visual Representation. Chicago: The University of Chicago Press, 1994.

MYERS, Kenneth John, and David C. MILLER, eds. "On the Cultural Construction of Landscape Experience: Contact to 1830." American Iconology: New Approaches to Nineteenth-Century Art and Literature. New Haven: Yale University Press, 1993.

NASH, Roderick. Wilderness and the American Mind. 1967. New Haven: Yale University Press, 1982.

NOVAK, Barbara. Nature and Culture: American Landscape and Painting, 1825-1875. 1980. New York: Oxford University Press, 1995.

ORVELL, Miles. “After 9/11: Photography, the Destructive Sublime, and the Postmodern Archive." Michigan Quarterly Review, vol. 45, no. 2, 2006, p. 239-256.

PARRY III, Ellwood C. “Overlooking the Oxbow: Thomas Cole's View from Mount Holyoke Revisited." American Art Journal, no. 34/35, 2003-2004, p. 6-61.

ROQUE, Oswaldo Rodriguez. "The Oxbow by Thomas Cole: Iconography of an American Landscape Painting." Metropolitan Museum Journal, vol. 17, 1982, p. 63-73. 
SAYRE, Henry M. "Surveying the Vast Profound: The Panoramic Landscape in American Consciousness." The Massachusetts Review, vol. 24, 1983, p. 723-742.

SCHUYLER, David. Frederic Edwin Church. Washington: National Gallery of Art, 1989.

STERNFELD, Joel. Oxbow Archive. Göttingen: Steidl, 2008.

luhringaugustine.com/exhibitions/joel-sternfeld3

or joelsternfeld.net/oxbow-archive.

Accessed 7 July 2021.

STERNFELD, Joel. When it Changed. Göttingen: Steidl, 2008.

STERNFELD, Joel. “Joel Sternfeld's best photographs-when climate change sinks in." The Guardian, 20 February 2013.

theguardian.com/artanddesign/2013/feb/20/joel-sternfeld-best-photographs-climate-change.

Accessed 10 October 2017.

SWEENEY, J. Gray. "Inventing Luminism: Labels are the Dickens.” Oxford Art Journal, vol. 26, no. 2, 2003, p. 93-120.

VAN NOY, Rick. "Surveying the Sublime. Literary Cartographers and the Spirit of Place." The Greening of Literary Scholarship. Ed. Steven Rosendale. Iowa City: The University of Iowa Press, 2002.

WALLACH, Alan, and David C. MILLER, eds. "Making a Picture of the View from Mount Holyoke." American Iconology: New Approaches to Nineteenth-Century Art and Literature. New Haven: Yale University Press, 1993.

WALLACH, Alan. “Thomas Cole's River in the Catskills as Antipastoral." The Art Bulletin, vol. 84, no. 2, 2002, p. 334-350.

WELLS, Liz. Land Matters: Landscape Photography, Culture and Identity. London: I.B. Tauris \& Co Ltd, 2011.

WILLIAMS, Michael. Americans and Their Forests: A Historical Geography. Cambridge: Cambridge University Press, 1989.

\section{NOTES}

1. "The Oxbow" is located in a valley near Northampton, Massachusetts.

2. Cole climbed to the summit of Mount Holyoke for the first time in 1833, and he wrote down his impressions of the area before painting the actual site. It is interesting to note how his description of the forest was mentally molded by the aesthetic categories of the time: the beautiful, the sublime and the picturesque. The sublime corresponds to the river source at the top of the "wild mountains" of New-Hampshire since the forest was then a synonym for the wilderness (Parry 11). The beautiful is used to describe a domesticated form of nature, where lush valleys surrounded by wooded hills display fertile fields and a few scattered elms. And to finish, the picturesque (the "Arcadian vales" in Cole's own words) is described in the following way: "its villages are rural places where trees overspread every dwelling, and the fields upon its margin have the richest verdure" (Parry 12). We can see how aesthetic concepts allow the painter to categorize swiftly the different types of forest landscapes, from the sublime to the picturesque, from an untidy and untamed mass of trees, to a single and almost decorative item, the tree. As underlined by Rick Van Noy: "The paradigm through which the land is discursively formed already exists, and contact is made within this matrix" (182). 
3. Dimensions: $511 / 2 \times 76$ in. (130.8 x $193 \mathrm{~cm})$.

4. In the exhibition catalogue Frederic Edwin Church, National Gallery of Art, 1988-89, David Schuyler says: "The first and ultimately profound influence on Church was Thomas Cole, with whom he began a two-year period of study in 1844. Cole had by then been the most famous and most respected landscape painter in America for almost twenty years, but he had never accepted a pupil" (34).

5. The verb "to landscape" was coined by W.J.T. Mitchell in Landscape and Power: "The aim of this book is to change "landscape" from a noun to a verb. It asks that we think of landscape, not as an object to be seen or a text to be read, but as a process by which social and subjective identities are formed. [...] Landscape, we suggest, doesn't merely signify or symbolize power relations; it is an instrument of cultural power, perhaps even an agent of power that is (or frequently represents itself as) independent of human intentions" (2002 1-2).

6. Roderick Nash's definition of the American wilderness: "In the early nineteenth century American nationalists began to understand that it was in the wildness of its nature that their country was unmatched. While other nations might have an occasional wild peak or patch of heath, there was no equivalent of a wild continent. And if, as many suspected, wilderness was the medium through which God spoke most clearly, then America had a distinct moral advantage over Europe, where centuries of civilization had deposited a layer of artificiality over His works. The same logic worked to convince Americans that because of the aesthetic and inspirational qualities of wilderness they were destined for artistic and literary excellence." (69)

7. Here is Wallach's exact definition: "The totalizing vision I have been describing might be called panoramic; however, I prefer the term panoptic for two reasons. First, it underscores the connections between vision and power: the ascent of a panorama tower provided the visitor with an opportunity to identify, at least momentarily, with a dominant view-Foucault's 'eye of power.' The second reason has to do with the mode of vision itself. That mode was both extensive and intensive; it therefore needs to be distinguished somewhat from the usual meanings associated with the word panorama. It was extensive or panoramic in the everyday sense of that term because it covered the entire lateral circuit of visibility; but it was also intensive or telescopic because it aspired to control every element within the visual field. Which was precisely the point of Bentham's panopticon" (Wallach 83).

8. In Pastoral Inventions: Rural Life in Nineteenth-Century American Art and Culture, Sarah Burns demonstrates that at that time Americanized elements of the pastoral tradition were progressively introduced in American literature, before appearing in the visual arts: "By the late eighteenth century an American translation of the classical European pastoral ideal had emerged, as language evolved from conventional Edenic or Arcadian imagery to accommodate a more direct perception of the North American climate, geography, flora, and fauna. Even then, however, writers tended to organize observed facts into recognizably pastoral designs" (13).

9. Most of the photographs studied here can be found on the online portfolio of the exhibition provided by Luhring Augustine, the art gallery representing Sternfeld, or on the artist's website.

10. David Schuyler explains: "In other paintings Cole chose to omit structures by slightly changing the angle to exclude human alterations to the landscape: his painting View from Mount Holyoke, Northampton, Massachusetts, after a Thunderstorm (The Oxbow) (1836), [...] is framed to omit the refreshment pavilion for tourists that had stood up at the top of the mountain since 1821 and was recorded in the first of two engravings of the site published by William Henry Bartlett in American Scenery and the view that T. Addison Richards engraved for American Scenery Illustrated (1854)" (32).

11. Genette defines the concept of "métatextualité" as such: "tout ce qui met [le texte] en relation, manifeste ou secrète, avec d'autres textes" (10).

12. "The second element will break (or punctuate) the studium. This time is it not I who seek it out (as I invest the field of the studium with my sovereign consciousness), it is this element 
which rises from the scene, shoots out of it like an arrow, and pierces me. A Latin word exist to designate this wound, this prick, this mark made by a pointed instrument: the word suits me all the better in that is also refers to the notion of punctuation, and because the photographs I am speaking of are in effect punctuated, sometimes even speckled with these sensitive points; precisely these marks are so many points. [...] This second element which will disturb the studium I shall therefore call punctum; for punctum is also: sting, speck, cut, little hole-and also the cast of the dice. A photograph's punctum is that accident which pricks me (but also bruises me, is poignant to me)" (Barthes 26-27).

13. "But the only way in which [Wall] felt able to work within this documentary tradition was to modify it through what he calls neo-realism in his work, or more succinctly, 'cinematography'-a staged photo" (Wall 11).

14. Ansel Adams (1902-1984), the famous landscape photographer and Californian environmental activist.

15. One of the many advantages of these old-fashioned cameras is the possibility to produce extra-large and good quality enlargements that were precisely used by Sternfeld for the Oxbow Archive exhibition.

16. Liz Wells reminds us of the fact that photography as a discursive system manipulates symbolism and mythology, just like any other art form: "Likewise, seasonal change, whereby the environment literally shifts in shapes and colours, also reminds us of regeneration and mortality - from dust to dust" (12).

17. He states that: "deep ecologists, ecofeminists and Heideggerian ecocritics identify the scientific revolution as an ecological disaster in and through which a primal authenticity was lost" (Garrard 63).

18. Here is Brunet's description of the Third View movement: "Les 'troisièmes vues' complètent sans doute sur divers points l'entreprise archéologique et conceptuelle des 'secondes vues'; mais elles forment aussi un commentaire sur l'évolution des sites - tous ou presque situés dans l'Ouest montagneux ou désertique - entre 1980 et 2000, commentaire assumé cette fois plus explicitement par le photographe Mark Klett. Par là, le RSP rejoint une tendance plus large de la photographie américaine contemporaine, pour laquelle la cause environnementale est devenue un thème important voire majeur, tant sur le plan global que sur le plan régional - dans l'Ouest en particulier, où la vigueur des mouvements écologistes est à la mesure des dégradations causées par les essais nucléaires, les pollutions chimiques, les circuits d'irrigation et de canalisation des eaux, sans oublier l'urban sprawl et la ghettoïsation des centres villes" (Brunet 13).

19. For a convincing synthesis of the contenders' arguments, see J.Grey Sweeney's comprehensive research paper: "Inventing Luminism."

20. "Yet I cannot but express my sorrow that the beauty of such landscapes are quickly passing away-the ravages of the axe are daily increasing-the most noble scenes are made desolate, and oftentimes with a wantonness and barbarism scarcely credible in a civilized nation. The wayside is becoming shadeless, and another generation will behold spots, now rife with beauty, desecrated by what is called improvement; which, as yet, generally destroys Nature's beauty without substituting that of Art" (Cole, 1836 12).

21. Linda Levitt's review of American Prospects would perfectly fit Oxbow Archive: "Without the context of their accompanying text, the photographs [...] could easily be misread as what they only appear to be: serene images of the urban, suburban, or rural landscapes" (Levitt qtd. in Böger 618). 


\section{ABSTRACTS}

American photographer Joel Sternfeld (born 1944) published Oxbow Archive in 2008, a book comprising 77 photographs that were taken over the course of a year and a half, between July 2005 and March 2007, and depicting a place called the East Meadows, located on the East side of the Connecticut river bend. Sternfeld chose the very place that was represented in Thomas Cole's famous View from Mount Holyoke, Northampton, Massachusetts, after a Thunderstorm-The Oxbow (1836). Sternfeld obviously resorts to intericonicity, but he has chosen to reverse the perspective completely, both from a visual and ideological viewpoint. Indeed, Sternfeld's images are no longer about the visual domination and appropriation of landscape in order to praise the conquest of the American territory; they put forward a new conception of the wilderness, based on aesthetic, political and ecological grounds. Sternfeld doesn't blatantly criticize the way men claim ownership of natural spaces, but prefers to use a rigorous and elaborate aesthetic framework, combined with a serial mode of representation that only shows traces of human presence. The series walks a fine line between the utopian / dystopian modes, without ever losing sight of the tension between the celebration of the American pastoral and ecological concerns. His work therefore can be analyzed through the prism of ecocriticism.

En 2009, le photographe américain Joel Sternfeld (1944-) publie un ouvrage intitulé Oxbow Archive, rassemblant 77 photographies, prises sur une durée d'un an et demi et se concentrant sur une zone géographique située à l'est du méandre de la rivière Connecticut, surnommé «The Oxbow », le lieu même représenté par Thomas Cole (1801-1848) dans le célèbre View from Mount Holyoke, Northampton, Massachusetts, after a Thunderstorm (1836). Si Sternfeld se place d'emblée dans la relation intericonique avec Thomas Cole, il choisit néanmoins de renverser totalement le point de vue. Cet article montre comment il ne s'agit plus, chez Sternfeld, de dominer le paysage visuellement, et de célébrer ainsi la conquête du territoire américain, mais de mettre en avant une nouvelle dimension de la forêt, esthétique et politique, tournée vers des considérations écologiques. Il ne met pas en image une critique ouverte et systématique de la manière dont l'homme s'approprie l'espace naturel; la critique est disséminée au sein d'un cadre esthétique rigoureux et amplifiée par le mode sériel. La série de Sternfeld ne perd jamais le fil de la dichotomie utopie / dystopie sur laquelle elle oscille, et la tension entre la célébration de la pastorale américaine et la revendication écologique demeure jusqu'au bout, rejoignant ainsi les préoccupations de l'écocritique.

INDEX

Mots-clés: peinture américaine, photographie américaine contemporaine, Sternfeld (Joel), paysage américain, écocritique, intericonicité, Cole (Thomas)

Keywords: American painting, contemporary American photography, Sternfeld (Joel), American landscape, ecocriticism, intericonicity, Cole (Thomas)

\section{AUTHOR}

\section{HELENA LAMOULIATTE}

Université Bordeaux Montaigne, CLIMAS EA4196 